\title{
ANALISIS FAKTOR WISATAWAN NUSANTARA MEMBELI TIKET PESAWAT KE BALI
}

\author{
NGAS. Dewi \\ Email: susrami_ipw@unud.ac.id \\ Program Studi Industri Perjalanan Wisata, Fakultas Pariwisata, Universitas Udayana
}

\begin{abstract}
The increasing number of airlines that provide flight routes to Bali, causes tourists to consider various factors before making the purchase of an airline ticket that would be used to go to Bali. This study aims to determine the factors that influence the decision of domestic tourists to purchase airline tickets to Bali with a quantitative descriptive approach. Data collected through observation, questionnaire distribution, and literature study. The sample in this study amounted to 100 tourists who were obtained accidentally. With the help of factor analysis using SPSS version 17, out of 26 indicators, six major factors were formed that influenced the behavior of domestic tourists in purchasing airline tickets to Bali, including: psychological factor, social factor, cultural factor, marketing mix factor, employment factor, and personal factor. The dominant factor that has influenced the behavior of domestic tourists in purchasing tickets is psychological factors with an eigenvalue of 14.135 and a variance percentage of $42.832 \%$. As for forming psychological factors, airline image factors got the biggest loading factor which is a number of 0.881 .
\end{abstract}

Abstrak: Semakin banyak maskapai yang menyediakan rute penerbangan ke Bali, menyebabkan wisatawan harus mempertimbangkan berbagai faktor sebelum melakukan pembelian tiket pesawat yang akan digunakan menuju Bali. Penelitian ini bertujuan untuk mengetahui faktor-faktor yang mempengaruhi keputusan wisatawan nusantara dalam melakukan pembelian tiket pesawat ke Bali dengan pendekatan deskriptif kuantitatif. Data dikumpulkan melalui observasi, distribusi angket, dan studi kepustakaan. Sampel dalam penelitian ini berjumlah 100 wisatawan nusantara yang diperoleh secara accidental. Dengan bantuan analisis faktor menggunakan SPSS versi 17, dari 26 indikator terbentuk enam faktor besar yang yang mempengaruhi perilaku wisatawan nusantara dalam pembelian tiket pesawat ke Bali, antara lain: faktor psikologis, faktor sosial, faktor budaya, faktor bauran pemasaran, faktor pekerjaan, dan faktor pribadi. Faktor dominan yang mempengaruhi perilaku wisatawan nusantara dalam pembelian tiket adalah faktor psikologis dengan nilai eigenvalue sebesar 14,135 dan persentase variance sebesar $42,832 \%$. Adapun di dalam pembentuk faktor psikologis, faktor citra maskapai mendapatkan loading factor terbesar, yakni sejumlah 0.881 .

Keywords: bali, consumer behavior, domestic tourists, flight ticket.

\section{PENDAHULUAN}

Pertumbuhan kedatangan wisatawan nusantara ke Bali tidak terlepas dari kemudahan akses menuju Bali itu sendiri. Bali dengan segala potensinya telah menarik minat banyak maskapai penerbangan untuk melebarkan sayap usahanya dengan menyediakan penerbangan menuju Bali. Berdasarkan pada observasi awal di Bandar Udara Internasional I Gusti Ngurah Rai Bali, terdapat 11 maskapai penerbangan yang melayani rute menuju ke Bali. Banyaknya maskapai penerbangan yang umumnya berebut pangsa pasar yang sama tentunya semakin memperketat persaingan usaha di antara para maskapai. Berbagai upaya pemasaran dilakukan oleh maskapai penerbangan guna meraih pelanggan sebanyak-banyaknya dan menjadikannya sebagai pelanggan yang loyal.

salah upaya maskapai penerbangan yang dapat kita cermati adalah fenomena tiket murah (low cost carrier) yang ditawarkan oleh banyak maskapai penerbangan di Indonesia, seperti Lion Air, AirAsia, dan Citilink. Fenomena tersebut nampaknya mampu menggeser image pesawat udara yang dulunya hanya untuk kalangan menengah ke atas dan kini mampu dijangkau kalangan menengah ke bawah. 
Transportasi udara diklaim sebagai moda transportasi yang paling aman dibandingkan dengan moda transportasi lain, hal tersebut karena persentase kecelakaan yang lebih rendah dibanding transportasi laut maupun darat, namun belakangan ini fenomena kecelakaan dan keterlambatan keberangkatan (delay) seakan menjadi cerminan buruk bagi pihak maskapai. Tercatat telah terjadi beberapa kecelakaan penerbangan komersial dalam satu dekade terakhir yang dialami oleh maskapai penerbangan komersial di Indonesia, seperti kecelakan pesawat Lion Air JT-904 pada 13 April 2013, AirAsia QZ8501 pada 28 Desember 2014, hingga Lion Air JT-610 pada tanggal 29 Oktober 2018 yang mana menjadi catatan buruk industri penerbangan (Yaspen Martinus, 2018). Selain itu, masalah keterlambatan keberangkatan pesawat (delay) yang marak terjadi juga menjadi catatan penting bagi maskapai penerbangan.

Fenomena kecelakaan dan keterlambatan keberangkatan pesawat udara nampaknya sedikit banyak memiliki pengaruh terhadap keputusan masyarakat untuk menggunakan pesawat udara sebagai moda transportasi menuju Bali. Jika dirata-ratakan, jumlah kedatangan pesawat dan penumpang di Bandar Udara I Gusti Ngurah Rai mengalami peningkatan, akan tetapi pada tahun 2015 jumlah kedatangan pesawat udara mengalami penurunan sebesar 3,50\% dan jumlah kedatangan penumpang mengalami penurunan sebesar $0,71 \%$, hal tersebut diprediksi karena munculnya ketakutan masyarakat untuk menggunakan pesawat udara menyusul terjadinya kecelakaan pesawat AirAsia pada Desember 2014. Catatan buruk dari beberapa maskapai penerbangan secara tidak langsung akan memberikan citra yang buruk kepada maskapai yang bersangkutan. Hal ini juga sekiranya akan berpengaruh pada keputusan pembelian tiket suatu maskapai oleh konsumen, dalam hal ini wisatawan sebagai salah satu konsumen jasa penerbangan. Menurut Kotler dan Keller (2007), perilaku konsumen sangat dipengaruhi oleh keadaan dan situasi lapisan masyarakat dimana ia dilahirkan dan berkembang. Ini berarti konsumen berasal dari lapisan masyarakat atau lingkungan yang berbeda akan mempunyai penilaian, kebutuhan, pendapat, sikap, dan selera yang berbeda-beda. Faktor yang mempengaruhi perilaku konsumen terdiri dari: faktor kebudayaan, sosial, pribadi, dan psikologis.

Berdasarkan latar belakang yang telah diuraikan, peneliti memandang perlu dilakukan suatu penelitian untuk mengetahui faktor-faktor yang mempengaruhi keputusan konsumen, dalam hal ini wisatawan nusantara dalam melakukan pembelian tiket pesawat ke Bali. Penelitian ini penting bagi para pelaku usaha jasa penerbangan guna mengidentifikasi pasar potensial sehingga maskapai penerbangan mampu merumuskan strategi pemasaran yang tepat sesuai dengan kebutuhan dan keinginan wisatawan.

\section{METODE}

Lokasi penelitian yang dipilih, meliputi: Pantai Kuta, Pusat Oleh-Oleh Krisna Tuban, dan Pantai Sanur, dengan alasan daya tarik wisata tersebut merupakan daya tarik yang banyak dikunjungi wisatawan nusantara, sehingga memudahkan proses pencarian responden. Peneliti menganalisis variabel dari faktor keputusan pembelian tiket pesawat oleh wisatawan nusantara, yang terdiri dari: faktor harga, faktor produk, faktor lokasi (Kotler dan Keller, 2007), faktor promosi (Cravens, 2003), faktor motivasi, faktor keamanan, dan faktor citra (Korpert dan Elliss, 2011). Teknik penentuan sampel dilakukan secara purposive, sedangkan dalam pengambilan sampelnya dilakukan secara accidental. Sampel responden yang didapatkan berjumlah 100 orang berdasarkan rumus Slovin yang selanjutnya dianalisis menggunakan Exploratory Factor Analysis. Selain penyebaran kuesioner, peneliti juga melakukan observasi dan studi kepustakaan sebagai teknik pengumpulan datanya.

\section{HASIL DAN PEMBAHASAN \\ Karakteristik Wisatawan Nusantara}

Berdasarkan usia, diketahui wisatawan milenial telah mendominasi pembelian tiket pesawat menuju Bali, yakni pada usia $22-26$ tahun dan 27 - 31 tahun dengan persentase masing-masing sebesar $34 \%$. Hal ini dikarenakan wisatawan nusantara yang melakukan pembelian tiket pesawat ke Bali berusia produktif, sehingga memiliki status finansial yang cukup dan motivasi yang tinggi untuk melakukan perjalanan wisata.

Menurut daerah asalnya, wisatawan nusantara yang melakukan pembelian tiket pesawat ke Bali paling banyak berasal dari Jakarta dengan 
persentase sebesar $25 \%$. Adanya aktivitas yang sibuk di perkotaan membuat wisatawan asal Ibu Kota banyak melakukan perjalanan wisata ke Bali.

Berdasarkan jenis kelaminnya, mayoritas wisatawan nusantara yang melakukan pembelian tiket pesawat ke Bali adalah wanita dengan persentase sebesar $57 \%$. Hal ini dikarenakan wisatawan nusantara wanita paling banyak ditemui selama penelitian.

Status perkawinan wisatawan nusantara yang paling banyak dalam pembelian tiket pesawat ke Bali adalah belum kawin dengan persentase sebesar 55\%. Berkaitan dengan mayoritas usia responden yakni 21-31 tahun, usia ini masih dalam tahap belajar (mahasiswa) ataupun dalam tahap meniti karir, sehingga membuat status perkawinan belum kawin mendominasi.

Pendidikan terakhir wisatawan nusantara yang paling banyak dalam pembelian tiket pesawat ke Bali adalah SMA dengan persentase sebesar 35\%, dikarenakan usia wisatawan nusantara yang melakukan pembelian tiket pesawat ke Bali didominasi oleh usia 21 - 31 tahun, dimana usia tersebut merupakan usia dalam tahapan mengenyam pendidikan.

Dari segi pekerjaannya, wisatawan nusantara yang membeli tiket pesawat ke Bali paling banyak berprofesi sebagai wiraswasta dengan persentase sebesar $30 \%$, dikarenakan tingkat pendidikan yang didominasi oleh SMA dan Sarjana, dimana pendidikan tersebut mampu memperjelas pekerjaan yang dominan yakni wiraswasta dan pelajar.

Pendapatan wisatawan nusantara yang paling banyak dalam pembelian tiket pesawat rute Denpasar sebesar > Rp.3.000.000 dengan persentase sebesar $45 \%$. Hal ini dikarenakan wisatawan didominasi dari Jakarta yang memiliki pendapatan besar sehingga mendominasi > Rp. 3.000.000.

Berdasarkan teman perjalanan, wisatawan nusantara yang membeli tiket penerbangan ke Bali paling banyak melakukan perjalanan bersama teman dengan persentase sebesar $43 \%$. Hal ini dikarenakan usia produktif membuat wisatawan lebih dekat dengan teman sepekerjaan atau teman seangkatan kuliah atau sekolah.

Frekwensi kunjungan ke Bali oleh wisatawan nusantara yang membeli tiket pesawat adalah tiga kali/lebih, dengan persentase sebesar $51 \%$. Hal ini dikarenakan Bali mudah diakses, rute penerbangan CGK -
DPS yang dilayani oleh maskapai memiliki frekwensi yang tinggi dalam sehari, dan Bali menjadi salah satu destinasi wisata favorit di Indonesia.

Pengatur perjalanan wisatawan nusantara yang paling banyak pada penelitian ini adalah seorang diri dengan persentase sebesar $55 \%$. Hal ini dikarenakan wisatawan nusantara yang berkunjung ke Bali lebih didominasi oleh wisatawan repeater. Wisatawan mengenali daerah tujuan wisata karena sudah pernah berkunjung sebelumnya.

Maskapai yang paling banyak digunakan oleh wisatawan nusantara ke Bali adalah AirAsia dengan persentase sebesar 23\%. Hal ini dikarenakan AirAsia menawarkan kemudahan dalam pembelian tiket melalui website, dan menawarkan bagasi gratis untuk rute domestik.

\section{Uji Validitas Instrumen}

Suatu kuesioner dikatakan valid jika pertanyaan pada kuesioner mampu mengungkapkan suatu yang akan diukur oleh kuesioner tersebut. Jika $\mathrm{r}$ hitung $>\mathrm{r}$ tabel 0,361 $\{\mathrm{df}=30-2(28)$ dengan Sig 5\% $\}$ dapat dilihat pada tabel $r$, maka pengukuran tersebut valid. Namun apabila $\mathrm{r}$ hitung $<\mathrm{r}$ tabel maka pengukuran tersebut tidak valid (Ghozali 2005). Perhitungan uji validitas ini dilakukan dengan Program SPSS 17.0 for windows. Seluruh indikator yang diuji validitasnya dapat dikatakan valid karena memiliki nilai lebih dari 0.361, sehingga akan digunakan dalam pengujian selanjutnya yaitu uji reliabilitas dan analisis data.

\section{Uji Reliabilitas Instrumen}

Uji reliabilitas dilakukan untuk memperoleh hasil penelitian yang reliabel. Jadi apabila instrumen tersebut digunakan beberapa kali untuk mengukur objek yang sama, akan menghasilkan hasil yang sama. Berdasarkan hasil analisis dapat dilihat bahwa dari hasil uji reliabilitas terhadap 30 responden, didapatkan hasil Cronbach's Alpha sebesar 0,963, nilai ini dikatakan telah memenuhi syarat atau reliable, karena nilainya lebih dari 0,6.

\section{Uji KMO and Bartlett}

Matriks korelasi dapat mengidentifikasi variabel - variabel mana saja yang terkait satu sama lain dari ke-33 variabel yang dianalisis. Nilai Bartlett's Test of Sphericity yang diperoleh pada output SPSS analisis faktor 
adalah 3005.253 dengan signifikansi 0,000. Hasil ini menunjukkan bahwa antara variabel terjadi korelasi dan dengan demikian peluang untuk terjadinya kesalahan pada variabel yang tidak independen sebesar $0 \%$. Nilai KMO yang diperoleh sebesar 0,853 , yang berarti angka ini menunjukkan syarat kecukupan yang sudah melebihi 0,5 dan memenuhi kriteria untuk dilakukan proses selanjutnya. Menurut Kaiser (1970) dalam Widarjono 2015 ukuran KMO yang didapatkan dalam penelitian ini berada pada ukuran berguna (Meritorious).

\section{Uji Measure of Sampling Adequacy}

Uji MSA dilakukan untuk mengukur derajat korelasi antar variabel, dimana setiap variabel dianalisis untuk mengetahui variabel mana yang layak untuk diproses lebih lanjut dan mana yang harus dikeluarkan. Variabel yang dapat diproses lebih lanjut, yaitu jika nilai MSA pada setiap variabel $>0,5$. Berdasarkan hasil analisis dapat diketahui bahwa dari ke 33 variabel yang ada, semua variabel memiliki nilai lebih dari 0,5 , dengan hasil ini maka semua variabel digunakan pada analisis selanjutnya karena memenuhi persyaratan nilai.

\section{Penentuan Jumlah Faktor}

Penentuan jumlah faktor dilakukan untuk menentukan berapa banyak faktor yang terbentuk mewakili variabel-variabel. Penentuan jumlah faktor ini berdasarkan pada besarnya eigenvalue setiap faktor yang muncul. Semakin besar eigenvalue setiap faktor, semakin representatif faktor tersebut untuk mewakili sekelompok variabel. Faktorfaktor inti yang dipilih adalah faktor yang mempunyai eigenvalue $\geq 1$. Berdasarkan hasil analisis dapat dijelaskan bahwa dalam tahap ini terbentuk tujuh faktor dari 33 variabel yang mempengaruhi keputusan pembelian tiket pesawat rute Denpasar. Ketujuh faktor tersebut memiliki eigenvalue > 1, yaitu 14.135, 3.182, 2.247, 1.846, 1.527, 1.356, dan 1.098 dengan nilai Cumulative eigenvalue sebesar $76.942 \%$.

\section{Rotasi Faktor}

Rotasi faktor merupakan langkah yang dilakukan untuk menyederhanakan matriks faktor itu sendiri. Matrik faktor yang terbentuk masih diidentifikasi, sehingga perlu dilakukannya rotasi faktor untuk menunjukkan hasil yang terstruktur dan lebih sederhana. Dengan cara ini dapat mempermudah penjelasan seluruh faktor yang dianalisis dalam model. Metode penelitian yang digunakan dalam penelitian ini adalah rotasi dengan metode varimax. Rotasi varimax dipilih karena memberikan hasil yang lebih mudah dianalisa secara teori. Berdasarkan hasil analisis maka dapat dipaparkan bahwa dari ke 33 variabel yang telah dirotasi, terdapat 26 variabel yang memenuhi syarat atau kriteria dikarenakan melebihi nilai loading factor sebesar 0,5 dan 7 variabel yang tidak memenuhi syarat atau kriteria dikarenakan nilai loading factor kurang dari 0,5 yaitu variabel Pengaruh Orang Terdekat (X2.1), Kelompok Sosial (X2.2), Kebutuhan (X4.1), Situasi dan Kondisi (X4.2), Kemudahan Mendapatkan Tiket (X5.7), Tampilan Pesawat (X5.8), dan Kepemilikan member (X5.12).

Adapun komponen variabel yang memenuhi kriteria, meliputi: faktor yang pertama terdiri dari Penghargaan terhadap keluarga (X1.3), Hasrat (X4.3), Persepsi terhadap rasa aman (X4.4), Persepsi terhadap ketepatan waktu (X4.5), Citra maskapai (X4.6), Pengalaman (X4.7), Pengetahuan terhadap maskapai (X4.8), Pelayanan staff (X5.5), Fasilitas tambahan yang ditawarkan (X5.9), Layanan boarding (X5.10), Kecepatan pengantaran bagasi (X5.11). Variabel lainnya masuk ke faktor yang kedua terdiri dari Strata sosial (X1.4), Peran sosial (X2.4), Status sosial (X2.5), Usia (X3.1). Variabel selanjutnya masuk ke dalam faktor yang ketiga yaitu Harga tiket (X5.1), Variasi harga (X5.2), Potongan harga (X5.3), Variasi jadwal (X5.6). Variabel berikutnya yang masuk ke dalam faktor keempat yaitu Pengaruh keluarga (X1.1), Kepercayaan keluarga (X1.2), Orientasi keluarga (X2.3). Variabel berikutnya yang masuk ke dalam faktor kelima yaitu Pekerjaan (X3.2), Promosi maskapai (X5.4). Variabel yang masuk ke dalam faktor keenam yaitu Pendapatan (X3.3), Kepribadian (X3.4). Sedangkan faktor ketujuh tidak mememiliki satupun variabel yang membentuk faktor.

\section{Interpretasi Faktor}

Pada penelitian ini, terdapat 26 variabel yang memenuhi syarat minimal loading factor sebesar 0,5. Berdasarkan hasil tersebut, maka dapat diketahui bahwa dari jumlah total 26 variabel yang dianalisis mampu melewati loading factor > 0,5 yang tergabung dalam enam faktor dan satu faktor yang tidak memiliki faktor pembentuk. 
Pada tahapan ini faktor yang merupakan gabungan dari suatu variabel harus diberi nama. Pemberian nama harus mengacu pada variabel-variabel yang membentuk faktor yang bersangkutan atau berdasarkan pada variabel yang mempunyai loading factor tertinggi dibandingkan variabel lain yang berada dalam satu faktor tersebut. Faktor-faktor baru yang telah terbentuk diberi nama sesuai dengan variabel yang telah dikelompokan. Hal ini dapat dapat diuraikan sebagai berikut:

1. Faktor pertama diberi nama faktor psikologis yang memiliki nilai eigenvalue sebesar 14.135. Adapun faktor psikologis terdiri dari atas penghargaan terhadap keluarga, hasrat, persepsi terhadap rasa aman, persepsi terhadap ketepatan waktu, citra maskapai, pengalaman, pengetahuan terhadap maskapai, pelayanan staff, fasilitas tambahan yang ditawarkan, layanan boarding, dan kecepatan pengantaran bagasi.

2. Faktor kedua diberi nama faktor sosial yang memiliki nilai eigenvalue sebesar 3.182. Adapun faktor sosial terdiri atas strata sosial, peran sosial, status sosial, dan usia.

3. Faktor yang ketiga diberi faktor bauran pemasaran yang memiliki nilai eigenvalue sebesar 1.465. Adapun faktor bauran pemasaran terdiri atas variabel harga tiket, variasi harga, potongan harga, dan variasi jadwal.

4. Faktor yang keempat diberi faktor budaya yang memiliki nilai eigenvalue sebesar 1.846. Adapun faktor budaya terdiri atas pengaruh keluarga, kepercayaan keluarga, dan orientasi keluarga.

5. Faktor yang kelima diberi faktor pekerjaan yang memiliki nilai eigenvalue sebesar 1.527. Adapun faktor pekerjaan terdiri atas variabel pekerjaan, dan promosi maskapai.

6. Faktor yang keenam diberi faktor pribadi yang memiliki nilai eigenvalue sebesar 1.356. Adapun faktor pribadi terdiri atas variabel pendapatan dan kepribadian.

\section{Faktor Perilaku Wisatawan Nusantara Membeli Tiket Pesawat ke Bali}

Faktor-faktor awal yang digunakan untuk melihat faktor yang mempengaruhi perilaku wisatawan nusantara dalam pembelian tiket ke Bali yaitu terdiri atas 33 indikator yang ada pada 5 faktor. Hasil yang diperoleh membentuk konsep baru, yang mana menunjukan bahwa dari 5 faktor awal dengan total 33 indikator di atas membentuk tujuh faktor baru, dimana salah satu faktor tidak memiliki faktor pembentuk sehingga dapat diabaikan persentase variance nya dan menjadi enam faktor terbentuk, setelah dilakukan rotasi maka faktor perilaku wisatawan nusantara dalam pembelian tiket pesawat ke Bali dan menghasilkan enam faktor terbentuk dengan 26 variabel didalamnya dengan 7 variabel yang dikeluarkan karena nilai MSA setelah faktor dirotasi kurang dari nilai standar yang sudah ditentukan.

Faktor pertama yaitu faktor psikologis yang terdiri dari atas (1) Penghargaan Terhadap Keluarga, (2) Hasrat, (3) Persepsi terhadap rasa aman, (4) Persepsi terhadap ketepatan waktu, (5) Citra Maskapai, (6) Pengalaman, (7) Pengetahuan terhadap Maskapai, (8) Pelayanan Staff, (9) Fasilitas tambahan yang ditawarkan, (10) Layanan Boarding, dan (11) Kecepatan Pengantaran Bagasi. Penamaan faktor psikologis berkaitan dengan konsep yang diterapkan oleh Kotler dan Keller (2007) bahwa faktor psikologis merupakan salah faktor-faktor yang mempengaruhi keputusan pembeli terhadap suatu produk.

Faktor kedua yaitu faktor sosial yang terdiri atas (1) Strata Sosial, (2) Peran Sosial, (3) Status Sosial, dan (4) Usia. Penamaan faktor sosial berkaitan dengan konsep yang diterapkan oleh Kotler dan Keller (2007) bahwa faktor sosial merupakan salah faktorfaktor yang mempengaruhi keputusan pembeli terhadap suatu produk.

Faktor ketiga yaitu faktor bauran pemasaran yang terdiri atas (1) Harga Tiket, (2) Variasi Harga, (3) Potongan Harga, (4) Variasi Jadwal. Penamaan faktor bauran pemasaran berkaitan dengan konsep yang diterapkan oleh Kotler dan Keller (2007) bahwa faktor bauran pemasaran merupakan salah faktor yang mempengaruhi keputusan pembeli terhadap suatu produk.

Faktor keempat yaitu faktor budaya yang terdiri atas (1) Pengaruh Keluarga, (2) Kepercayaan Keluarga, (3) Orientasi Keluarga. Penamaan faktor budaya berkaitan dengan konsep yang diterapkan oleh Kotler dan Keller (2007) bahwa faktor budaya merupakan salah faktor dari lingkungan calon pembeli yang mempengaruhi keputusan pembeli terhadap suatu produk.

Faktor kelima yaitu faktor pekerjaan yang terdiri atas (1) Pekerjaan, dan (2) Promosi maskapai. Penamaan faktor pekerjaan 
berkaitan dengan konsep yang diterapkan oleh Kotler dan Keller (2007) bahwa faktor pekerjaan merupakan salah faktor-faktor yang mempengaruhi keputusan pembeli terhadap suatu produk.

Faktor keenam yaitu faktor pribadi yang terdiri atas variabel (1) Pendapatan, dan (2) Kepribadian. Penamaan faktor pribadi yang berkaitan dengan konsep yang diterapkan oleh Kotler dan Keller (2007) bahwa faktor pribadi merupakan salah dari dalam diri yang mempengaruhi keputusan pembeli terhadap suatu produk.

\section{Faktor Dominan Wisatawan Nusantara Membeli Tiket Pesawat ke Bali}

Adapun faktor perilaku wisatawan nusantara yang paling dominan dalam pembelian tiket pesawat ke Bali dapat dilihat melalui nilai eigenvalue dalam analisis faktor yaitu sebesar 14.135. Berdasarkan hasil penelitian, maka yang menjadi faktor paling dominan yaitu faktor psikologis, faktor ini terdiri dari sebelas indikator pembentuk yaitu: (1) Penghargaan Terhadap Keluarga, (2) Hasrat, (3) Persepsi terhadap rasa aman, (4) Persepsi terhadap ketepatan waktu, (5) Citra Maskapai, (6) Pengalaman, (7) Pengetahuan terhadap Maskapai, (8) Pelayanan Staff, (9) Fasilitas Tambahan yang Ditawarkan, (10) Layanan Boarding, dan (11) Kecepatan Pengantaran Bagasi. Faktor psikologis, mengungguli faktor lain dengan persentase variance sebesar $42.832 \%$ dan nilai eigenvalue sebesar 14.135. Faktor psikologis merupakan faktor perilaku wisatawan nusantara utama dalam pembelian tiket pesawat ke Bali, berhubungan dengan konsep yang diterapkan oleh (Kotler dan Keller, 2007) bahwa faktor faktor yang mempengaruhi keputusan konsumen salah satunya faktor psikologis dimana pembeli akan mempertimbangkan persepsi, pengetahuan, pengalaman, citra dan keyakinan mereka bila mereka akan melakukan pembelian. Hal ini menunjukkan bahwa penciptaan sebuah konsep teori harus berbanding lurus dengan keadaan di lapangan. Hasil penelitian ini diperkuat oleh penelitian Amri (2017), yang membuktikan bahwa faktor budaya, sosial, pribadi dan psikologis berpengaruh signifikan dan positif terhadap perilaku konsumen maskapai penerbangan Lion Air dalam melakukan pembelian tiket pesawat melalui $e$-Commerce.
Kondisi di lapangan terkait dengan faktor psikologis yang diberikan oleh maskapai dalam pembelian tiket pesawat ke Bali berbeda tergantung dari maskapai yang digunakan oleh wisatawan, namun dalam penelitian ini, maskapai yang mendominasi adalah AirAsia yang saat ini menjadi maskapai paling diminati oleh wisatawan nusantara karena menawarkan bagasi gratis untuk penerbangan rute domestik. Kemudian, citra dari maskapai yang menyediakan rute penerbangan domestik menuju Denpasar sangat mempengaruhi keputusan wisatawan nusantara dalam pembelian tiket pesawat, dimana citra maskapai yang rendah akan menurunkan persepsi keamanan bagi wisatawan. Oleh karena itu, keputusan pembelian tiket pesawat ke Bali oleh wisatawan domestik didominasi oleh faktor psikologis wisatawan.

\section{SIMPULAN DAN SARAN Simpulan}

Berdasarkan hasil penelitian ini, peneliti dapat menyimpulkan bahwa: pada perilaku wisatawan nusantara dalam pembelian tiket pesawat rute Denpasar, terdapat enam faktor yang terbentuk dengan 26 variabel didalamnya, antara lain: faktor psikologis yang terdiri dari 11 faktor pembentuk; faktor sosial yang terdiri atas 4 faktor pembentuk; faktor bauran pemasaran yang terdiri atas 4 faktor pembentuk; faktor budaya yang terdiri atas 3 faktor pembentuk; faktor pekerjaan yang terdiri atas 2 faktor pembentuk; dan faktor pribadi yang terdiri atas 2 faktor pembentuk.

Faktor dominan yang mempengaruhi perilaku wisatawan nusantara dalam pembelian tiket ke Bali adalah faktor pertama yang diberi nama faktor psikologis. Faktor psikologis, mengungguli faktor lain dengan persentase variance sebesar $42.832 \%$ dan nilai eigenvalue sebesar 14.135. Oleh karena itu, faktor psikologis merupakan faktor utama yang mempengaruhi perilaku wisatawan nusantara dalam pembelian tiket pesawat ke Bali. Adapun faktor pembentuk yang memiliki nilai loading factor tertinggi pada faktor psikologis adalah citra maskapai dengan loading factor 0,881 .

\section{Saran}

Maskapai yang menawarkan rute ke Bali (Denpasar) memberikan perhatian lebih kepada citra maskapai, dengan cara melakukan 
publikasi mengenai prestasi yang diraih ataupun hal-hal positif terkait maskapai;

Maskapai yang menawarkan rute ke Bali (Denpasar) memberikan perhatian kepada kualitas pelayanan yang diberikan kepada wisatawan sebagai konsumen, dengan cara melakukan inovasi unik dan kreatif dalam melayani wisatawan sehingga psikologis wisatawan terpengaruh untuk membeli tiket dari maskapai tersebut.

Maskapai yang menawarkan rute ke Bali (Denpasar) harus lebih menekankan pada faktor keamanan, dengan cara memberikan informasi yang jelas mengenai standar-standar keamanan maupun mengenai asuransi kecelakaan yang diterima oleh wisatawan baik pada saat pre-flight maupun in-flight. Selain itu, perusahaan dapat memfasilitasi tiap pesawat dengan alat keamanan yang memadai dan mampu berfungsi dengan baik kepada wisatawan sebagai konsumen, sehingga akan terbentuk persepsi mengenai rasa aman dari wisatawan dan mempengaruhi mereka untuk membeli tiket pada maskapai tersebut.

On Time Performance (OTP) maskapai juga harus selalu dijaga, agar tertanam pada benak wisatawan mengenai ketepatan waktu maskapai tersebut dan akhirnya mempengaruhi psikologis wisatawan untuk membeli tiket pada suatu maskapai tertentu 


\section{Kepustakaan}

Amri. (2017). Analisis Perilaku Konsumen Maskapai Penerbangan Dalam Melakukan Pembelian Tiket Pesawat Melalui E-Commerce. Jurnal Ekonomi dan Manajemen STIE Pertiba Pangkalpinang, Vol. 3, No. 2, hh. 1-15.

Cravens, David. W. (2003). Strategic Marketing. Chicago: The Mc Graw Hill Coy, Inc.

Ghozali, Imam. (2005). Aplikasi Analisis Multivariate Dengan Program SPSS. Semarang: Badan Penerbit Universitas Diponogoro.

Kotler dan Kevin Lane Keller. (2007). Manajemen Pemasaran Edisi 12 Jilid 1. Jakarta: PT Indeks.

Widarjono, Agus. (2015). Statistika Terapan Dengan Excel \& SPSS. Yogyakarta: UPP STIM YKPN.

Yaspen Martinus. Kecelakaan Pesawat di Indonesia. Tersedia pada http://wartakota.tribunnews.com/2018/1 0/29/ini- daftar-kecelakaan-pesawat-diindonesia-sejak-tahun-2000-yangmerenggut-korban-jiwa [diunduh pada 3 Februari 2019]. 